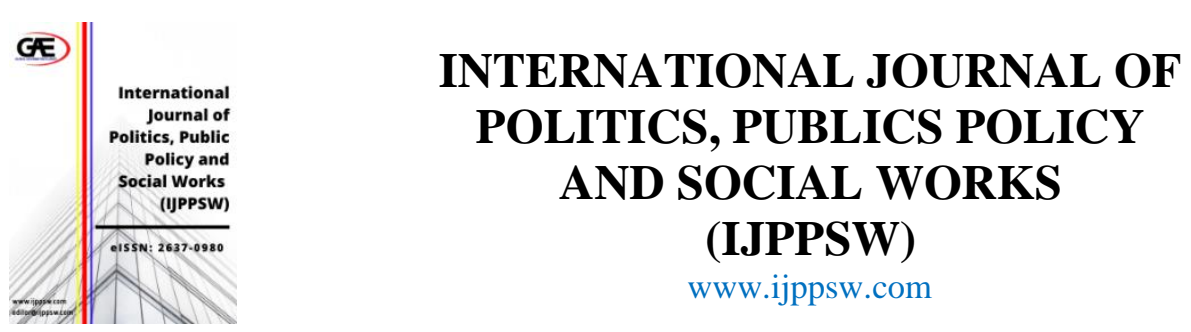

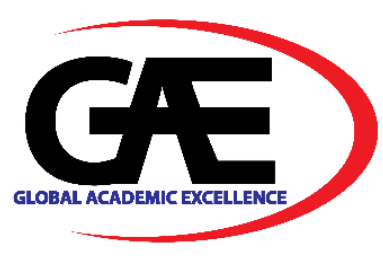

\title{
USING SOCIAL MEDIA FOR POLITICAL CAMPAIGN COMMUNICATION AND ITS IMPACT ON POLITICAL POLARIZATION AMONG YOUTHS IN UGANDA
}

Faiswal Kasirye ${ }^{1}$

1 Department of Communication, International Islamic University Malaysia, Malaysia Email: kasirye.faiswal@gmail.com

\section{Article Info:}

\section{Article history:}

Received date:01.05.2021

Revised date: 31.05 .2021

Accepted date: 10.06.2021

Published date: 15.06.2021

\section{To cite this document:}

Kasirye, F. (2021). Using Social Media for Political Campaign Communication and Its Impact on Political Polarization among Youths in Uganda. International Journal of Politics, Publics Policy and Social Works, 3 (9), 17-43.

DOI: $10.35631 /$ IJPPSW.39003.

This work is licensed under CC BY 4.0

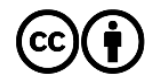

\begin{abstract}
:
The current study is aimed at examining the use of social media for political communication and its impact on the political polarization of youths in Uganda. The study specifically focuses on determining social media platforms that are often used by youths in Uganda, find out the levels of social media usage, political campaign communication, and political polarization among youths in Uganda as a result of social media usage. Lastly, the study also focuses on determining the relationship between social media platforms, social media usage, political communication, and political polarization amongst youths in Ugandans. The study adopts the uses and gratifications theory to help in guiding the study and explaining the available relationships between the variables of the study. A quantitative research design and survey method with a questionnaire as the tool for data collection were used in this study. 192 valid responses were extracted from youths residing in Kampala and Wakiso districts in Uganda as the respondents of the study. The findings of the study reveal that youths in Uganda often use Facebook, WhatsApp, Twitter, and Instagram while looking for political-related information to help them form a decision on who to give their support in the election. In addition, the study also reveals that the more the youths look for such political information, the more they become polarized because all the politicians just feed them with information that is divisive and there exists a huge amount of hatred as a result of the consumption of such information on the Ugandan internet space. The uses and gratifications theory is also supported in the study.
\end{abstract}

\section{Keywords:}

Social Media, Politics, Political Campaign Communication, Political Polarization, Politics In Uganda, Uses And Gratifications Theory 


\section{Introduction}

In our daily lives, people hardly escape from communication in social, economic, and political spheres. These range from children to adults, regular people in our communities to politicians. All the above groups need communication to express their thoughts and concerns about any issues they may be facing in their lives. Therefore, communication has enabled people to discuss various issues, make social construction on them, and figure out a lasting solution to deal with them.

Information communication technology (ICT) has essentially altered how we access information, communicate and work with other peers, and engage in political processes. In Europe, $72 \%$ of the people go online daily, and over half of them engage in social networks (Eurostat, 2017). Not only that but, social media is now also fully embedded in political communication. Most political parties and candidates around the world have an online presence and digital targeting has now become an indispensable tool in any politician's electoral gear, with campaigners developing increasingly winning digital strategies in every election cycle.

Political campaigning is one of the most expensive and sophisticated marketing tools in the world. To inform and persuade voters, candidates on the different levels rely on a variety of communication strategies, including advertising, print and broadcast media, and selling themselves to voters at mass gatherings during the entire campaign period. Moreover, during the past few years, we have largely observed politicians adopting new communication technologies such as social media where they can do free campaigning to their followers. So far, the available literature has shown mixed evidence that entirely adopting social media as a communication technology helps brands to which politicians during such periods act as brands that have to sell themselves to the consumers who are the voters (Gong et al., 2017; Gans et al., 2016; Laroche et al., 2013 and Kumar et al., 2013).

This question is very timely and pertinent as we head into Uganda's Presidential and parliamentary elections in 2021, due to increased interest in social media's influence on electorates. Therefore, this paper seeks to find out how social media campaigning impacts political polarization in the Ugandan social media space.

The immense acceptance of information and communication technologies among the populace has also allowed new forms of political engagements. Platforms like Facebook, Twitter, WhatsApp, and others are now allowing more subscribers than ever before to connect over shared interests. Its usage has however left a very huge gap in understanding how it impacts the general population while polarizing them. Furthermore, From the available studies (Gil de Zúñiga, Veenstra, Vraga, \& Shah, 2010 and Margetts, John, Hale, Yasseri, \& John, 2015) majorly in the west, they have shown that the internet can be a powerful tool for political communication and social activism by encouraging acts of participation that turn into online movements. The movements finally in one way or the other lead to polarization and huge divisions among users.

While the coming of the internet birthed freedom of expression and democratic renewal, there is now a growing concern that the very technologies that once promised to set us free are polarizing democracy through social media politics. This has already manifested in the European political context and largely becoming a reality in the African setting as well, where government actors have expressed fears about the role of the internet and connected devices in 


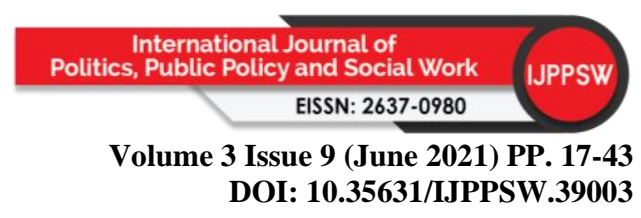

the spread of viral online misinformation and increased legal scrutiny around the power of ICT companies and their recurrent encroachments on data protection and intellectual property law.

Social media usage today is not limited to daily conversations but has been extended to political communication. The interactive and flexible nature of social media has made it now widely used by members of the public, politicians, and political parties in political communication. It has now been a tool for political campaigns and communication. However, politicians should be wise while using social media for political communication as its usage presents several advantages and disadvantages, especially for ordinary people but also for the new and incumbent politicians.

\section{Statement of the Problem}

While it is largely acknowledged that well-functioning institutions require compromise and the capacity for citizens to engage with a variety of political viewpoints freely, the situation is increasingly worrisome, especially in the democratic world. This issue is lessened by a widespread sentimentality that our societies are falling victims to radical voices and becoming more polarized. Currently, these concerns have mounted in Africa where digital technology is being singled out as the root cause of growing partisan divides and deepening social inequalities among the electorates and the populace at large as Yasseri, and John (2015) concluded in their study.

Recent political events around the world have also shown that technology can be manipulated with a categorical intention of influencing politics. For example, Cases such as Russia's suspected highly mediatized interference in the 2016 US presidential election exposed social media's ambiguities and showed how easily their business models can be exploited with a deliberate goal of polarizing people (Neudert \& Marchal, 2019).

This study examines the impact of using social media in political campaign communication. More specifically, we focus on politicians' adoption of social media and its effect on political polarization among Ugandans while running for different political offices. Throughout the study, we focus on mainly how Facebook, Instagram, YouTube, and Twitter adoption may lead to differential benefits for new politicians with the more experienced ones as well as those from the ruling party and their opposition opponents with their contributions in dividing the populace as a result of their influence on social media.

Biased social media usage increases polarization among members of the public. Its usage for political communication also encourages the establishment of groups within the society based on political ideology and preferences because of the always divided opinions among the politicians and the populace at large (Gans et al., 2016). This is mostly because social media users tend to establish friendships and communication with users who share the same political preferences and ideology. In Uganda for example, Facebook, Twitter, and Instagram have divided electorates into opposition and the ruling party as the only political groups that share political spaces in the country. They often share the same political space on social media and indulge in insults against each other and camps using the power of the internet.

However, it is not clear whether this type of engaging the public is useful for politicians in shifting political competition in Uganda since the country is very much divided on political arena where the youths are demanding their share of wanting higher political positions and 


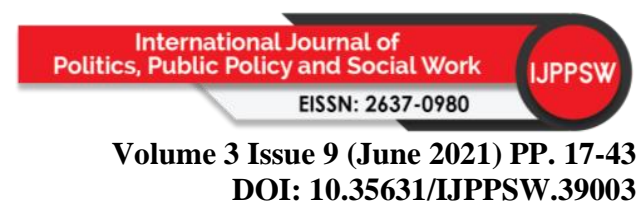

therefore resort to the internet and make use of it to sway the different groups of people especially the youths who are the majority in the country.

Documenting such data as a result of adopting social media is above all important because, there is evidence in literature where several earlier studies have concluded that, incumbents in any election hold significant financial and informational advantages over newcomers (Ansolabehere \& Snyder, 2000; Prat, 2002 and Prior, 2006). This usually brings in polarization among the politicians and their supporters for a large lack of fairness on all levels. We ask whether adopting social media can mitigate polarization among the politicians along with the ordinary electorates by allowing new politicians access to an alternate, relatively cost-effective technology to communicate with their constituencies about their candidacy and raise awareness about their manifestos. This is turn will help in understanding the impact of political polarization among Ugandans as a result of using social media by asking questions like; what is the level of social media usage among Ugandan youths? What is the impact of political polarization as a result of social media usage among Ugandan youths? What is the level of Uganda's political communication on social media? and what is the relationship between social media usage, political communication, and political polarization amongst youths in Kampala?

\section{Research Objectives}

The main objective of this study is to examine the impact of political polarization as a result of using social media for political campaign communication among Ugandan youths.

The specific objectives are:

1. To determine the social media platforms that are often used by youths in Uganda;

2. To assess the level of social media usage, political campaign communication, and political polarization as a result of social media usage among youths in Uganda; and

3. To determine the relationship between social media platforms, social media usage, political communication, and political polarization amongst youths in Ugandans.

\section{Significance of The Study}

Notably, many studies have been done relating to social media usage in politics. However, in the African context, it is still limited particularly in Uganda where research on social media is limited since using social media as a political communication tool is relatively a new phenomenon. Therefore, this study is timely due to a huge increase in social media usage, importance, and popularity among Ugandans. Consequently, the present paper attempts to examine the use of social media as a political campaign communication tool and its impact on the political polarization of Ugandan youths.

In line with the above, the findings of this study are expected to contribute to a greater body of knowledge in campaign political communication and polarization on social media under the framework of uses and gratifications theory. Several studies (Gil de Zúñiga et al., 2010 and Margetts et al., 2015) on the usage of social media for political campaigning and communication with voters have been done using the same theory although predominantly in the west and few studies have addressed the issue in the African context and Uganda in particular. Therefore, the current paper will be very important because it will be focusing on the Ugandan context especially since the country is headed for polls in 2021 and therefore filling the gap highlighted above in research on the usage of social media for political communication and its impact on political polarization in Uganda. 


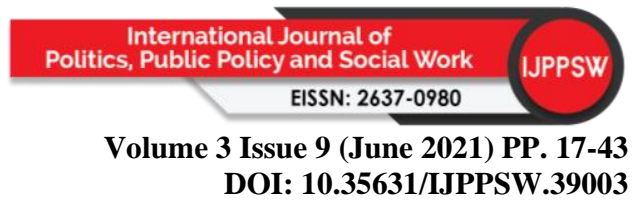

Furthermore, since previous studies like that of Williams and Gulati $(2007,2009)$ have not sufficiently addressed the specific impact of political polarization as a result of using social media for political campaigning to the policy makers and parliamentarians in Uganda, the findings of the current study will provide useful information to the policy makers like the ministry of ICT and the government, in particular, to better understand how to deal with political groupings and politicians that encourage polarization and constant divisions with the sole purpose of dividing and inciting the general population into hating either group.

The current study could also be instrumental in enhancing communication between politicians and their followers as well as ordinary people who are constant users of social media, and it will assist them in developing developmental programs, that will help in enhancing people's understanding of the current issues and the implementation of their particular political manifestos in Uganda.

The study will also act as a guiding tool to the social media users, politicians, and political parties regarding political campaigning using social media. The impact of political polarization on social media users and voters in general if explored and highlighted will be of great importance to the people in trying to avoid such biased opinions from cheap politicians who always aim at dividing the populace. Therefore, the study will inform the government on the dangers and advantages of using social media as a tool for political campaigning for their future regulation.

In a practical sense, the study will help Ugandan politicians in preparing them for the forthcoming campaign period which has been carried out largely online as a result of decreasing the spread of the current COVID-19 pandemic that requires few numbers in such meetings and discourages rallies that might bring thousands of people together. Consequently, it will help them in informing them of the advantages and disadvantages of using this type of political communication to their electorates in search of their support.

\section{Literature Review}

\section{Social Media Usage}

Social media platforms have been swamped with user groups of all ages and backgrounds in Uganda. But what exactly does social media mean, especially when so many technological platforms fall under the term in popular verbatim? For example, on Facebook and Instagram, users create a personal profile where they post their messages, images, and links to online content, all of which eventually flow into a pool of newsfeed. Millions of messages are sent through WhatsApp, an encrypted peer-to-peer messaging app for mobile devices, every day. Also, on Snapchat, which is popular with mostly youngsters or millennials, images and videos disappear within seconds of being opened. Users of TikTok also record short videos with sound clips that manage to always penetrate through to becoming viral content to the public. Given the huge number and diversity of platforms, it is debatably unsurprising that the all-inclusive definition of social media remains contested.

Boyd and Ellison (2007) set out a framework for future research with a currently widely-cited definition of social media. They defined it as networks that allow users "to construct a public or semi-public profile within a bounded system, articulate a list of other users with whom they share a connection and always view and navigate their list of connections, and those made by others within the system" (p. 37). 


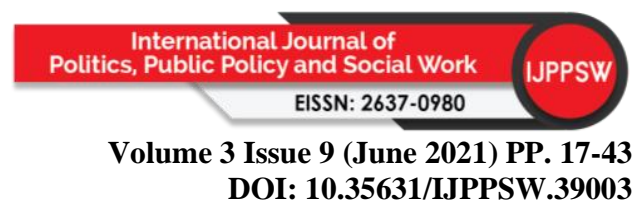

The role of social media has of late meant to mean producing and distributing digital content in form of personal messages, news, ideas, as well as the people, organizations, and industries that produce and consume the content through social media (Howard \& Parks, 2012). Also, worthy to note is that social media companies themselves are rarely content creators but rather, mediators that make the content visible to users via search, recommendation, and relevance algorithms (Gillespie, 2014). in other words, the users become the creators in this regard.

In Uganda, over the past few years, social media has become universal, transforming in ways that citizens, corporate, and political actors access, share and present information on the different platforms. According to a January 2020 report by the data Trends insight (datareportal), there are more than 10million Internet users in Uganda, making it 24\% of the total population. That number shows a huge increase of 3.5\% just between the years of 2019 and 2020. In addition, out of the 10 million internet users, 2.5 million users are connected to the different social media platforms by January 2020. This also puts the increase in usage of social media to 27\% between April 2019 and January 2020, putting its penetration at 5.6\% in that regard and most of them are mobile phone internet users (Datareportal, 2020).

Uganda's most popular social media site is Facebook, according to a January datareportal (2020) report. Facebook has remained tight-lipped about regional user numbers, but the company reported that it has 2.23 billion monthly active users since 2018 worldwide (Facebook Newsroom, 2019). In the Ugandan context, chat applications such as WhatsApp and Messenger are both owned by Facebook which also has a very large active user base. Instagram, Twitter, and Snapchat are further examples of other popular social networks that are commonly used by Ugandans in their various social, economic and political activities. Since the invention of social media several decades ago, tens of thousands of users in Uganda have integrated these platforms into their daily lives.

\section{Social Media Usage and Political Communication}

Earlier studies have focused on social network sites and their usage in political environments. Williams and Gulati (2007, 2009) examined the extent to which Facebook was used by Congressional candidates during election campaigns in the United States. They found out that, the number of Facebook supporters can be considered a valid indicator of electoral success.

Presently, social media usage has now been extended from mere daily conversations to political communication. Both members of the public and politicians use social media for different political purposes. While members of the public use social media for discussing political matters, and engaging with civil society organizations and political leaders; the vast majority of politicians use it as a campaigning medium for maintaining their public image, and as a communication medium for sustaining engagement with journalists and their potential audience (Howard et al., 2017). Therefore, it is not surprising that social media channels today are filled with political discussions in addition to daily conversations.

For example, in the context of the 2016 Ugandan elections, Roosblad (2016) found out that, Facebook offered young people a platform and an opportunity to express their views freely, and also for politicians and political parties to reach individuals that were less interested in politics. Their study concluded that viewing a candidate's profile on social media strengthens voter's existing attitudes. On the other hand, politicians who react to the comments of users are perceived as more favorable. Kushin and Kitchener (2009) also explored the use of Facebook for online political discussions. Their results indicated that Facebook is a reasonable platform to discuss political issues. In addition, the discussions nowadays appear to have succeeded in 


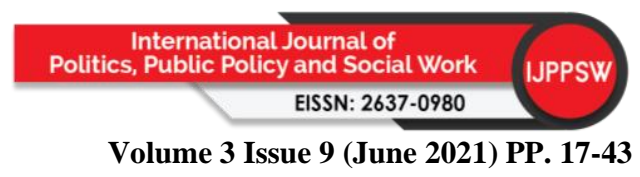

DOI: 10.35631/IJPPSW.39003

overcoming the polarization of social media discussion that has infused online political communication in the past.

However, it remains an open question whether the outcome of these social media political discussions informs political decision-making in the form of votes amongst users. In a study by Zhang et al. (2010), the researchers found out that, relying on social network sites such as Facebook and Twitter was positively related to civic participation but not to political participation or confidence in government. Rather, interpersonal discussions would foster both civic participation and political activity.

In Uganda, several political actors have now turned to social media platforms to seek political support. Some of them now hold online political talks that are intended to sway voters from their rival political parties. This has been common in especially new political comers who are mostly young politicians and intent to attract and convince the minds of young people that they claim to have been poisoned by the lies of the ruling government. Therefore, political communication on most of the social media platforms benefits a lot to the political actors whereas some of them tend to polarize the voters by preaching hate speech among voters.

Considering the power of social media platforms presently, politicians in Uganda tend to embrace social media communication as one of their strategies to communicate with their potential audiences as Nulty et al. (2016) concluded in their study. furthermore, alongside traditional media, social media have now been turned into the main platforms for a political campaign to gain support from potential electorates, to raise funding for political parties, and other political activities.

Other works from several scholars focus on the use of Twitter by citizens in political contexts. Tumasjan et al. (2010) in their study from data collected from Twitter show that, Twitter is extensively used for political deliberation and that the mere number of party mentions accurately reflects the election result. In other words, microblogging messages on Twitter reflect the political landscape in Uganda and can be used to predict election results especially among the youths who often use the platforms in most parts of urban areas in Uganda. In addition, Conover et al. (2011) examined two networks of political communication on Twitter, comprised of more than 250,000 tweets from the six weeks leading up to the 2016 U.S. elections. The authors revealed that the network of political retweets exhibited a highly segregated partisan structure, with extremely limited connectivity between the users.

There are several important roles social media plays in political communication. It increases the effectiveness and efficiency of a political campaign. Also, a political campaign using social media can be more effective and efficient in targeting potential electorates. Empirical examples have shown that social media can be used for a political campaign and support the offline campaign strategy.

Secondly, it plays an important role in bringing politicians closer to their electorates. Unlike traditional media, social media allows politicians and their audiences to directly communicate. This communication can take place everywhere at a different time and with different agendas. Finally, it can also mediate political communication with broader audiences. Social media usage in international political contexts has time and again helped politicians to communicate with broader audiences from different nationalities and languages. This helps people who live in those places to connect and be alive to what is going on in their mother countries (Nulty et al., 2016). 


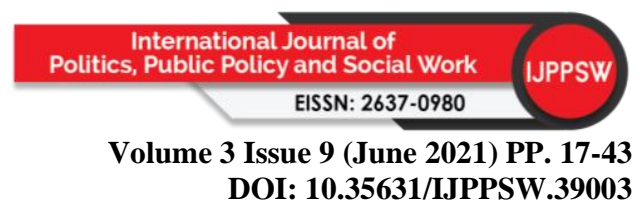

This study argues that social media play supporting roles in political communication between members of the public, politicians, and political parties. Alongside traditional media, social media provides an alternative avenue for political communications, make it more direct and interactive among the users. Using social media, members of the public can now target public officials and politicians to convey their aspirations, ideas, and criticism over political issues concerning the services that are given to them.

\section{Political Polarization}

Polarization is a complex concept employed almost universally in the media to express disagreements in public opinion (DiMaggio, Evans, \& Bryson, 1996). It is most commonly applied about political or ideological polarization, the former being the process by which a population splits into two distinct groups with contrasting views on political issues (Isenberg, 1986), and the latter the measure of ideological distance between them.

The concept of polarization might also mean divisions within a society, like social and affective polarization. Social polarization, for instance, describes the seclusion of society into separate groups depending on economic and cultural factors such as income inequality, race, religion, or lack of jobs and real estate markets (Iyengar, Sood, \& Lelkes, 2012).

Social media has transformed the way information is produced, consumed, and shared over the internet. Over the last decade, the spread of the internet has democratized access to information for extensive sections of the populace (Eurostat, 2018). In such circumstances, when faced with a large volume of information available in digital environments, human attention has also emerged as a limited resource, and those who succeed in commanding it can leverage attention for economic, political, or social gain (Wu, 2016). With the adoption of technology platforms as gossipmongers of news content, media companies have had to adapt their publishing strategies, including what type of content they push, as well as when and in what format they do so, to meet the demands of increasingly competitive online news consumers.

Uganda as a country is grappling with political polarization especially with regards to the ruling party in government and the several other opposition political parties. This escalates to the tribes, nepotism among the government workers, and several other divisions that are created as a result of inequality in the way the government handles its business.

\section{Social Media Usage and Political Polarization}

Partisan news coverage of politics on social media has been found to contribute to polarization by increasing the salience of partisan attitudes. Social media with partisan cues has been studied lengthily in that respect. Accordingly, Levendusky (2013) in his study argues that by presenting politics as a struggle between opposed parties that cannot reconcile, social media makes audiences' partisan identities more salient, thus contributing to both perceptive and affective divisions. Furthermore, Garrett et al. (2016) reveal that exposure to the ideologically biased social platform is positively associated with holding inaccurate beliefs on politically relevant issues even if people are aware of the facts contradicting such beliefs.

The increasing amount of distrust, together with institutional changes at every level as exhibited on social media platforms Facebook in particular has lessened the ties between government and the ordinary people, and an ongoing trend towards the abandonment of traditional party politics (Nielsen \& Kuhn, 2014), has only aggravated the political alienation of electorates, and this situation has been exploited by majority forces. 


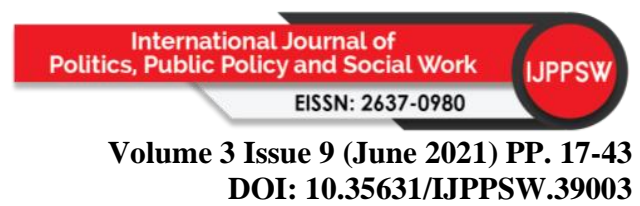

In politicized environments, different messages can help wage directional goals achieving attitude consistency even in the face of attitude-disconfirming information developing beliefs based on information one believes to be true (Stroud 2011). Also, Partisan news plays an important role in voters' likelihood of believing in rumors. In their study, Weeks and Garrett (2014) found that "exposure to rumors about a particular candidate is positively related to believing in the said rumors from members of both parties, but the relationship is significantly stronger when the rumor is attitude-consistent" (p. 409).

Relatedly, Berinsky (2017) concluded that political rumors on social media are more effectively corrected by unlikely sources which may turn out to be people who argue against their personal and political interests than by sources that are expected to be opposed to that particular content on social media and their political implications.

Also, information that emphasizes partisan divides can increase polarization, regardless of the partisanship of the source and the audience watching it. By contrast, messages that emphasize intra-party disagreement can reduce polarization, and this may be the case when the sources of these messages normally take contrary stands.

However, negative attitudes toward certain groups of people are an important component of polarization, in both their cognitive and affective lengths. Similarly, negative perceptions of certain people also may enhance beliefs in false information about those particular groups of people. As Kosloff et al. (2010) argue, "When people are viewed as different, negative labeling can be accomplished smoothly because there is little harm in attributing all manner of bad characteristics to them" (p. 384).

In the Ugandan context, beyond technological advances and their insightful impact on public life, Ugandan politics has been evolving in ways that could account for current levels of polarization in the general public. The political and financial scandals that define the country right from the financial crisis, the pandemic, the widespread corruption, and the unpopular politics of brutality that has been meted on the populace by the security organizations in the country have all dented public confidence in traditional political institutions, and hence increased divisions among the people as it was contended by Nielsen \& Kuhn (2014).

It is clear from the above discussions that using social media as a platform for political communication has both advantages and disadvantages for the public. It is, therefore, worth considering how to deal with the polarization and its impact on Uganda's political environment to advance the benefits of using social media for political communication among the people without decisive biased views.

\section{Uses and Gratification Theory (UGT)}

Developed by Blumler and Katz (1974), The uses and gratification theory (UGT) refers to the study of the gratifications or benefits that attract and hold users to different media and various contents that fulfil the user's emotional and social needs (Harridge-march et al., 2010). The primary objective of UGT is to clarify the reasons why people choose a specific type of medium to improve the understanding of social and individual gratifications and also to explain users' motives when interacting with the media. For example, Cheung et al. (2011) stated that the UGT explains why people use specific media as an alternative communication medium and discovers the needs that motivate the user to use a particular medium. They also noted that users are very much aware of their needs and their behaviour is goal-directed. 


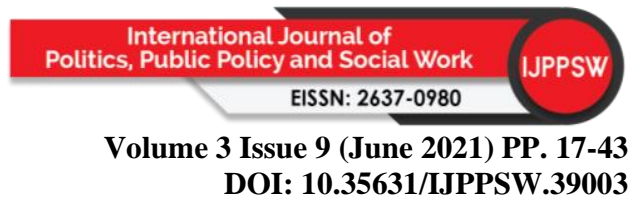

The theory assumes that media is goal-directed whereby people are motivated to consume it, that it is also selected based on the expectation that it will satisfy specific needs and desires. It also suggests that media influence on behaviour is filtered through social and psychological factors. It also assumes that people are always in control of the media and therefore barely influenced by it. Therefore, it stresses the power that a person has over that of the media (Communication studies, 2020).

In incorporating the uses and gratification theory in social media studies, scholars like Ruggiero (2000) have noted that new media includes several attributes that weren't part of older forms of media. Nowadays, users have greater control over what they interact with when they interact with it, and more content choices. This opens up the number of gratifications that new media use specifically social media could satisfy.

UGT has been recently used to explore new media and communication technologies such as SNS (Al-Jabri et al., 2015; Hsiao et al.,2015), mobile SNS (Gan et al.,2017), online games (Li et al.,2015), virtual communities (Cheung \& Lee, 2010). Cheung et al. (2011) applied UGT to examine the motivations for using Facebook by students and found that social factors had the most significant impact on the usage. Dhir and Tsai (2017) also incorporated UGT to understand the intensity of Facebook use and suggested that the UGT process plays a significant role in predicting the intensity of Facebook usage.

Earlier studies on uses and gratifications of the internet (Song, Larose, Eastin \& Lin, 2004) found seven gratifications for their use: information seeking, aesthetic experience, monetary compensation, diversion, personal status, relationship maintenance, and virtual community. The virtual community could be considered a new gratification as it has no parallel in other forms of media.

For social media gratifications, scholars (Park, Kee, \& Valenzuela, 2009) found out four needs for Facebook group participation. These included socializing by staying in touch and meeting people, entertainment through the use of Facebook for amusement or leisure, seeking selfstatus by maintaining one's image, and seeking information to learn about events and products. Similarly, Chen (2011) in his study on the gratifications of Twitter uncovered, that Twitter users gratified their need for connection through it. Besides, its increased usage, in terms of active time on Twitter and in terms of the number of hours one spends using the platform, increased the gratification of the need for connection.

From the discussions above, it is crystal clear, that UGT was the right choice of theory to help in guiding the current study considering that some of the gratifications and uses that have been explored before as a result of using the UGT include information seeking and social influence, attributes that politicians often aim at while distributing their political material on the different social media platforms for the ultimate consumption of their followers.

\section{Conceptual Framework}

This paper posits that there is a relationship between social media usage, political communication, and political polarization amongst Ugandans. To test the relationships between the variables namely; social media usage, political communication as the independent variable, and political polarization as the dependent variable. The following hypotheses in figure 1 are proposed for the study. 


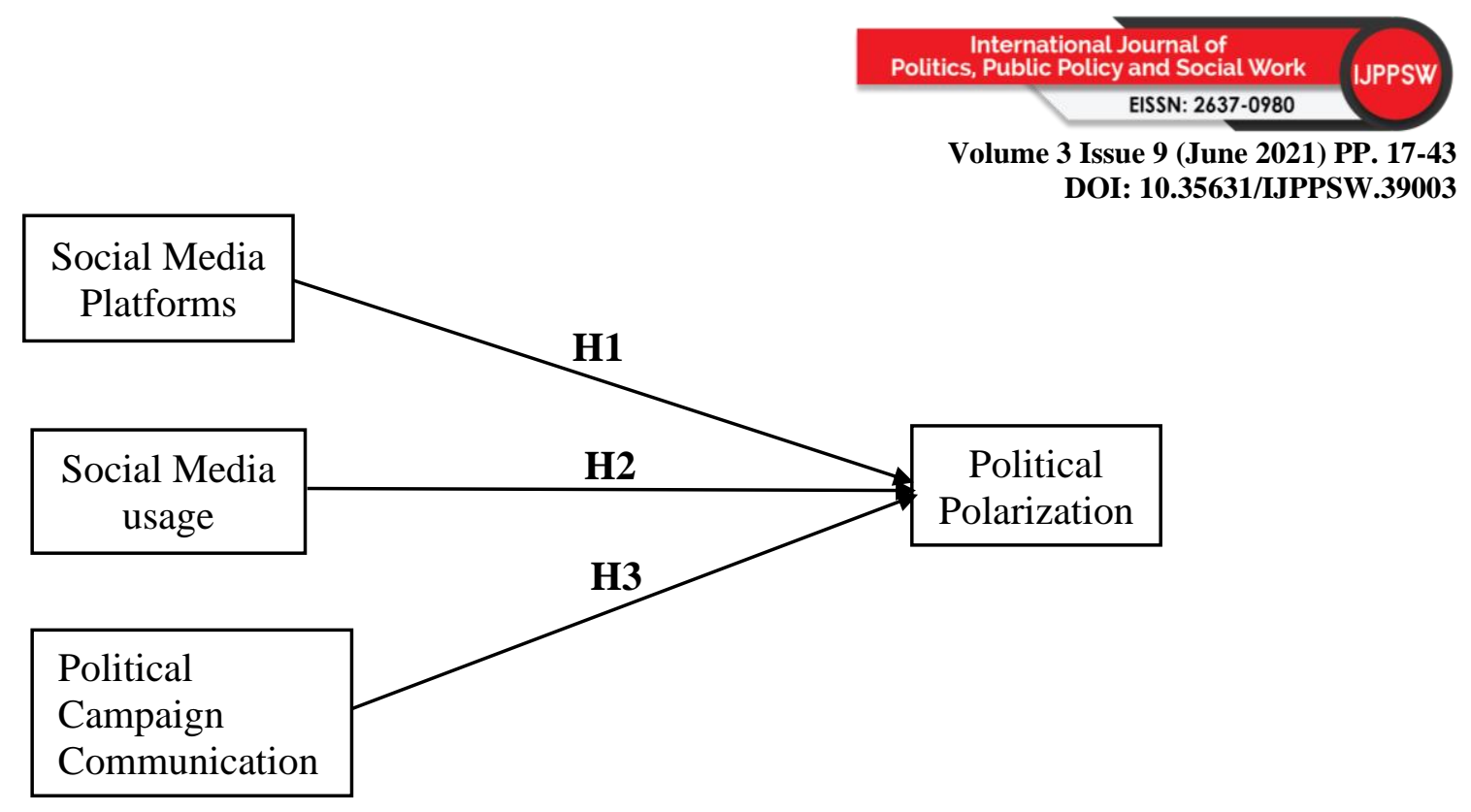

\section{Figure 1: Conceptual Framework Showing The Relationship Of Political Polarization With Social Media Platforms, Social Media Usage, And Political Campaign Communication}

\section{Summary of Hypotheses}

H1: There is a positive relationship between social media platforms used and political polarization.

H2: There is a positive relationship between Uganda's social media usage and political polarization.

H3: There is a positive relationship between political campaign communication and political polarization in Uganda.

H4: There is a relationship between social media usage political campaign communication and political polarization among Ugandans.

\section{Research Methodology}

\section{Research Design and Method}

The study employed a quantitative research design using the survey as the method. This method is suitable for collecting large sets of data in a short time. Data will be gathered using a selfadministered questionnaire as the data collection technique. Descriptive design was applied in the study to define the characteristics associated with the subject population to depict accurate profiles of the respondents. Also, this method was chosen because it allows sufficient data gathering on the respondents from the numerous levels of age, gender, nationality, level of education, year of study and more of the descriptive as Creswell (2014) concluded. Additionally, the survey method is considered in this study because it helps in gathering more information on independent and dependent variables regarding the phenomenon under study in a systematic way that is distinguishable from other data collection methods (Groves, 2011).

\section{Population of the Study}

The population of the study is citizens of Uganda who reside in both Kampala and Wakiso districts. These were chosen under the assumption, that the two districts have the biggest number of youths who daily use social media (UBOS, 2015) as compared to other districts in the country that make up its population of more than 45 million people. Also, the study is very timely because the country is undergoing presidential and parliamentary elections and currently in the campaigning period and therefore, these two districts determine the winner of the 


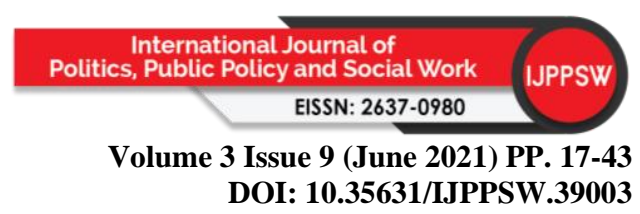

supreme office in the country because of their geographical location. Therefore, the residents there is, qualify to answer the questionnaires that will be used in data collection.

\section{Sampling and Technique}

A valid sample size of 192 respondents was obtained through probability random sampling, where the population has an equal chance of randomly being selected to participate in the study. This type of sampling increases the level of reliability of the findings, and it also has the best chance to create a sample that is truly representative of the population (Saunders et. al, 2007). The scholars also argue that the more data collected, the more reliable it becomes. Consents were sought from the respondents before giving them the questionnaires for filling.

\section{Research Instrumentation and Measurement}

The questionnaire that will be used for data collection in this study will be structured into four sections. Section 1 features the general data on demographics of the respondents whereas sections 2, 3, 4, and 5 were adapted from different scholars who have already studied the current phenomenon under study. This adapted items from other research studies to get accurate items and constructs that have already been tested and for their reliability. Therefore, Section 2 focuses on social media platforms used (10 items) developed by the researcher. Section 3 assesses the respondent's social media usage with 10 items. Besides, section 4 on campaign political communication has 10 items, and lastly, section 5 assesses the political polarization of the respondents with 17 items. Sections 2, 3, and 4 will be treated as the independent variables of the study whereas section 5 is the dependent variable.

Multiple questions in this study will be measured on a 5-point Likert-like scale for sections 2,3,4 and 5 to capture the extent to which respondents agree with the phenomenon under study. The Likert-like scale ranges from $1-5$, where $1=$ never and $5=$ always for sections 2,3 , and 5 , while section 4 uses strongly disagree to strongly agree. To calculate the overall percentage of an item, the mean score for each item will be multiplied by 20 based on the 5-point scale that is equivalent to $100 \%$ (Wok \& Hashim, 2014). Therefore, an overall percentage will be acquired by multiplying the mean score by 100 and dividing by 5 .

There are four variables to be considered in the survey namely; social media platforms often used, social media usage, political campaign communication, and political polarization The above variables carried items that were based to measure the extent to which respondents agreed with the statements therein, to which they helped the researcher by giving their answers through the survey.

\section{Validity and Reliability}

A pilot study $(\mathrm{N}=30)$ was conducted before the actual study to measure the flow of the items and or statements in the constructs, and to see whether any problems may have been faced by the respondents in the pilot test while answering the questionnaire. The questionnaire was also reviewed and approved by an expert in the field of measurement and quantitative survey studies to avoid research bias being reflected in the questions asked in the questionnaire. Internal reliability tests were conducted using Cronbach's alpha to indicate the reliability and significance of the variables and whether they exceed the minimum Cronbach's Alpha value of 0.70 to indicate the reliability, internal cohesiveness, and consistency of the variables (Franklin and Ballan, 2001). Also, face validity was done by the researcher by making sure that the results and findings of the study will be able to be generalized to other contexts as Omwuegbuzie and Johnson (2006) argue concerning external validity in research studies. The 


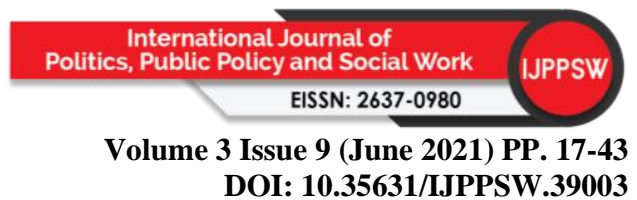

data collected from the pilot study indicate that all items in the variables were significant and exceeded the minimum Cronbach's alpha of . 70 to indicate the reliability of the variables with campaign political communication $(\alpha=.897)$, social media usage $(\alpha=.854)$, political polarization $(\alpha=.840)$ and types of social media platforms $(\alpha=.648)$. based on the results from the pilot study, the results were reliable to continue to the actual study where social media usage yielded $(\alpha=.919)$, campaign political communication $(\alpha=.916)$, political polarization $(\alpha=.892)$, and types of social media platforms used $(\alpha=.704)$ were found to be reliable for the study.

Table 1: Summary of the Reliability Test for the Given Variables of the Study

\begin{tabular}{|c|c|c|c|c|}
\hline Sections & \multirow[t]{2}{*}{ Variables $(N=192)$} & & \multicolumn{2}{|c|}{ Cronbach's alpha } \\
\hline & & $\begin{array}{l}\text { No. of } \\
\text { items }\end{array}$ & $\begin{array}{c}\text { Pilot }(\mathbf{N}= \\
\text { 30) }\end{array}$ & $\begin{array}{c}\text { Actual } \\
\text { Study }(N= \\
192)\end{array}$ \\
\hline 2 & Types of Social Media platforms & 10 & .648 & .704 \\
\hline 3 & Social Media Usage & 10 & .854 & .919 \\
\hline 4 & $\begin{array}{l}\text { Campaign } \\
\text { Communication }\end{array}$ & 10 & .897 & .916 \\
\hline 5 & Political Polarization & 17 & .840 & .892 \\
\hline
\end{tabular}

\section{Data Collection}

The instrument used for data collection in this study was a self-administered survey questionnaire using two methods, namely, (1) face-to-face self-administered questionnaire and (2) online survey using a Google form, after which responses as data will be computed for analysis. Data from both the face-to-face questionnaire and the online Google form was collected in Wakiso and Kampala districts for an estimation period of three weeks. Selfadministered questionnaires ensure that the respondents are free from the pressure of impressing the researcher. They also help to save the researcher's time and cost in addition to minimizing researcher bias (Creswell \& Creswell, 2017). Before the collection of the data, however, a pilot study was done. Data was conducted from the $5^{\text {th }}$ of January 2021 until January $25^{\text {th, }}$ 2021. The total number of respondents was 192 Ugandan youths who reside in Kampala and Wakiso districts. This study only considered residents of both Kampala and Wakiso because they live near the central business district and most of the political activities happen around the two areas. Each questionnaire took about 10 minutes to be filled up.

\section{Data Analysis}

Data were collected, coded, cleaned, and analyzed using Statistical Package for Social Sciences (SPSS) Version 23. Descriptive and inferential analyses were done where descriptive included frequencies, percentages, means, and standard deviation. Whereas for inferential statistics, a one-sample $t$-test was used to analyze research objectives 1 to 4 , and bivariate correlation and regression analyses were employed to measure the relationships of the variables, and therefore hypotheses 1 to 3 were answered.

\section{Results and Findings}

\section{Demographic Information}

The study comprised 192 valid respondents. Table 2 shows the demographic characteristics of the respondents based on gender, age, level of education, residential area, and the frequency of social media usage and platforms. Results in the table below show that six in ten of the Copyright $\odot$ C GLOBAL ACADEMIC EXCELLENCE (M) SDN BHD - All rights reserved 


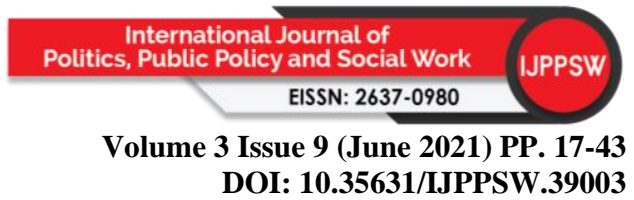

respondents $(66.1 \%)$ are male compared to $33.9 \%$ who are female respondents. On their age, $30.7 \%$ fall under the age group of $21-25,28.6 \%$ are in the $36-30$ age group, $20.8 \%$ under $31-$ $35,17.7 \%$ are above 36 years old and older while $2.1 \%$ are 20 years old and younger. On the respondent's highest level of education, $28.1 \%$ have ordinary/A-level and degree respectively, whereas others were diploma $(25.0 \%)$, postgraduate form $(11.0 \%)$ and the rest $(7.8 \%)$ have at least a primary level education. Also, slightly half $(58.3 \%)$ of the respondents live in urban areas compared to the rest $(41.7 \%)$ who put up in rural areas. The findings translate that; a majority of the respondents were male between the ages of 21-35 years living in urban areas with at least an ordinary/A-level certificate and as well as a degree as their highest level of education.

Table 2: Demographic Characteristics of the Respondents

\begin{tabular}{llll}
\hline Demographic & Category & Frequency & Percentage \\
Characteristic & Male & 127 & 66.1 \\
& Female & 65 & 33.9 \\
Agender & Total & $\mathbf{1 9 2}$ & $\mathbf{1 0 0 . 0}$ \\
& Less than 20 & 4 & 2.1 \\
& $21-25$ & 59 & 30.7 \\
& $26-30$ & 55 & 28.6 \\
& $31-35$ & 40 & 20.8 \\
& 36 and above & 34 & 17.7 \\
& Total & $\mathbf{1 9 2}$ & $\mathbf{1 0 0 . 0}$ \\
& Primary & 15 & 7.8 \\
Highest Level of education on & Ordinary/A-Level & 54 & 28.1 \\
& Diploma & 48 & 25.0 \\
& Degree & 54 & 28.1 \\
& Master & 13 & 6.8 \\
& PhD & 8 & 4.2 \\
Residential Area & Total & $\mathbf{1 9 2}$ & $\mathbf{1 0 0 . 0}$ \\
& Urban & 112 & 58.3 \\
& Rural & 80 & 41.7 \\
& Total & $\mathbf{1 9 2}$ & $\mathbf{1 0 0 . 0}$ \\
\hline
\end{tabular}

\section{Frequency of Social Media Usage}

On the respondent's frequency and time of usage of the social media and the platforms, seven in ten $(78.6 \%)$ of the respondents access social media using their smartphones while the rest (21.4\%) use laptops, iPad/tabs as well as desktop computers to access their social media platforms. On the average minutes spent on social media per sitting in minutes, results show that $25.5 \%$ use social media for more than an hour, followed by those who use it between 4660 minutes with (25.0\%), 31-45 minutes (21.9\%), 16-30 minutes (19.3\%) and lastly, $8.3 \%$ for those who use it for less than 15 minutes. In addition, on the average minutes that respondents spend while searching for political information per sitting, the results show almost half $(40.1 \%)$ of the respondents spend more than an hour, 46-60 minutes (27.6\%), 31-45 with (16.7\%), 1630 minutes (10.4\%) and the rest (5.2) spend less than 15 minutes on social media looking for political information. Furthermore, the results also show that in a day, 34.4\% spend more than 5 times using social media, followed by those who use it four times a day with (23.4\%), thrice a day (19.3\%), twice a day (13.5\%) and $9.4 \%$ for those who use social media once a day. Additionally, a majority (80.2\%) of the respondents use social media more than five times a Copyright (C) GLOBAL ACADEMIC EXCELLENCE (M) SDN BHD - All rights reserved 
Volume 3 Issue 9 (June 2021) PP. 17-43 DOI: 10.35631/IJPPSW.39003

week, $17.2 \%$ four times a week, and $2.6 \%$ use it at least twice a week. All in all, $22.9 \%$ of the respondents regard using social media in politics as slightly important, $20.3 \%$ as important, followed by $19.8 \%$ saying that it is not important at all, $18.8 \%$ very important, and lastly, $18.2 \%$ look at it as not important.

The results translate that majority of the respondents use smartphones to access social media where they spend more than an hour using in a day and weekly while looking for political information. Also, most of them regard it as slightly important in politics.

Table 3: Frequency and Time Spent on Social Media Usage

\begin{tabular}{|c|c|c|c|}
\hline Demography & Category & Frequency & Percentage \\
\hline & Desktop & 9 & 4.7 \\
\hline & Laptop & 18 & 9.4 \\
\hline \multirow{5}{*}{$\begin{array}{l}\text { The device used on Social } \\
\text { Media }\end{array}$} & Smartphone & 151 & 78.6 \\
\hline & Ipad/ Tablet & 14 & 7.3 \\
\hline & Total & 192 & 100.0 \\
\hline & $\begin{array}{l}\text { Less than } 15 \\
\text { minutes }\end{array}$ & 16 & 8.3 \\
\hline & $16-30$ minutes & 37 & 19.3 \\
\hline \multirow{6}{*}{$\begin{array}{l}\text { Time spent on social media } \\
\text { per sitting (in minutes) }\end{array}$} & 31-45 minutes & 42 & 21.9 \\
\hline & 46-60 minutes & 48 & 25.0 \\
\hline & $\begin{array}{l}61 \text { minutes and } \\
\text { above }\end{array}$ & 49 & 25.5 \\
\hline & Total & 192 & 100.0 \\
\hline & $\begin{array}{l}\text { Less than } \\
\text { minutes }\end{array}$ & 10 & 5.2 \\
\hline & $16-30$ minutes & 20 & 10.4 \\
\hline \multirow{5}{*}{$\begin{array}{l}\text { Time spent (in minutes) } \\
\text { looking for political } \\
\text { information per siting }\end{array}$} & 31-45 minutes & 32 & 16.7 \\
\hline & $\begin{array}{l}46-60 \text { minutes } \\
61 \text { minutes and } \\
\text { above }\end{array}$ & $\begin{array}{l}53 \\
77\end{array}$ & $\begin{array}{l}27.6 \\
40.1\end{array}$ \\
\hline & Total & 192 & 100.0 \\
\hline & once a day & 18 & 9.4 \\
\hline & Twice a day & 26 & 13.5 \\
\hline \multirow{5}{*}{$\begin{array}{l}\text { Frequency of accessing } \\
\text { social media in a day }\end{array}$} & Thrice a day & 37 & 19.3 \\
\hline & Four times a day & 45 & 23.4 \\
\hline & $\begin{array}{l}\text { Five times and } \\
\text { above }\end{array}$ & 66 & 34.4 \\
\hline & Total & 192 & 100.0 \\
\hline & Twice a day & 1 & 0.5 \\
\hline \multirow{2}{*}{$\begin{array}{l}\text { Frequency of accessing } \\
\text { social media in a week }\end{array}$} & Thrice a day & 4 & 2.1 \\
\hline & Four times a day & 33 & 17.2 \\
\hline
\end{tabular}




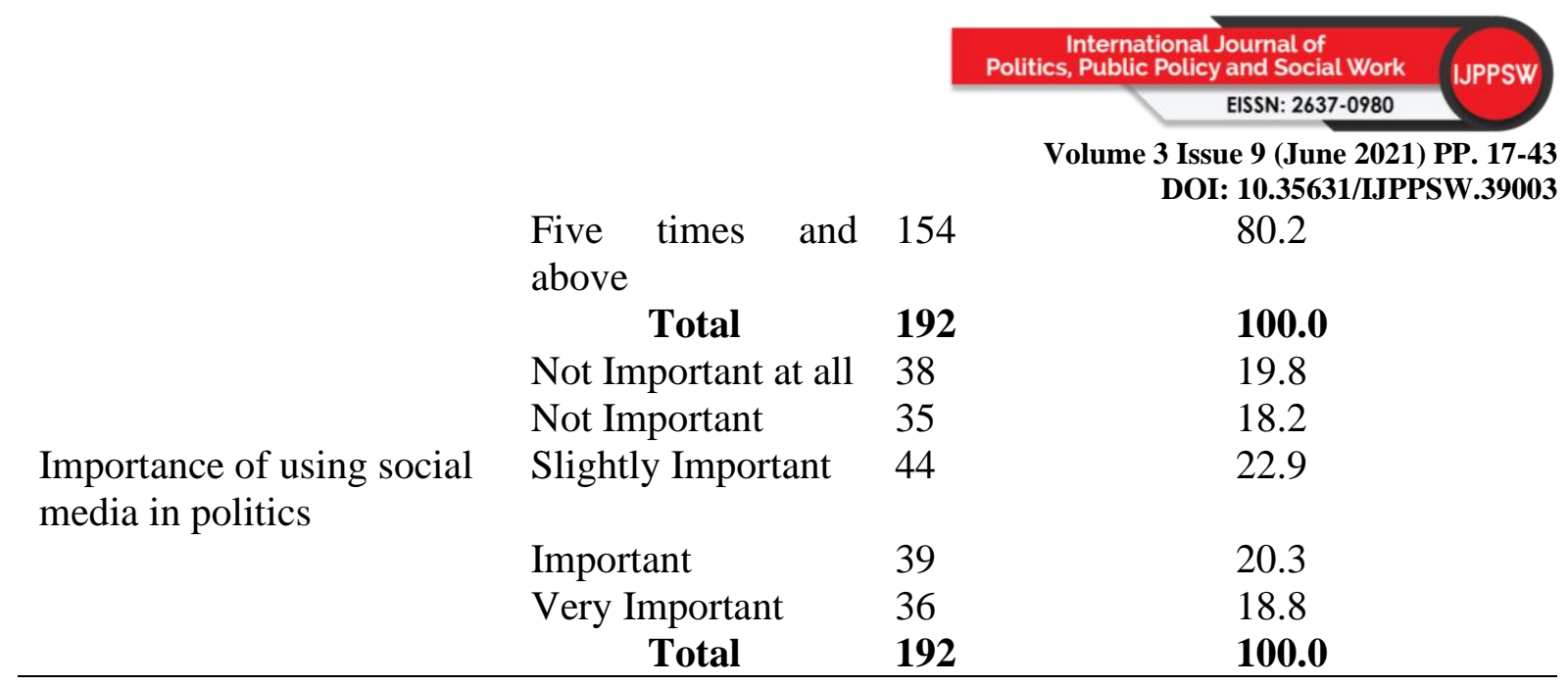

\section{Level of Types of Social Media Platforms}

Table 4 represents summarized findings from one sample t-test done on the level of types of social media platforms used. Results indicate that, on the whole, six in ten $(61.0 \%)$ of the respondents have mixed feelings in the way they regard and use the types of social media platforms $(M=3.052 ; S D=0.376)$ with a t-value of $1.937(\mathrm{p}=.054)$. This result indicates that the respondents regard highly and often use some of the platforms which include; Facebook (82.3\%), WhatsApp (80.0\%), Twitter (78.2\%), messenger (68.8\%), YouTube (63.7\%), and Instagram (60.3\%). However, the respondents also indicated that they hardly use platforms such as telegram, TikTok, LinkedIn, and Snapchat while looking for political information from social media. these items also exhibited significant but negative t-values after the test. The results, therefore, mean that the respondents regard some platforms highly because they often use them in looking for political information from social media while other platforms are not used for such purposes.

Table 4: One-sample t-test for the Types of Social Media Platforms

\begin{tabular}{|c|c|c|c|c|c|c|c|}
\hline No. & Types of social media platforms & $\mathbf{M}^{*}$ & SD & $\%$ & $t * *$ & $d f$ & $\rho$ \\
\hline 1 & Facebook & 4.119 & 0.850 & 82.3 & 18.238 & 191 & .000 \\
\hline 2 & WhatsApp & 4.000 & 0.812 & 80.0 & 17.060 & 191 & .000 \\
\hline 3 & Twitter & 3.911 & 0.925 & 78.2 & 13.651 & 191 & .000 \\
\hline 4 & Messenger & 3.442 & 1.128 & 68.8 & 5.434 & 191 & .000 \\
\hline 5 & YouTube & 3.187 & 1.182 & 63.7 & 2.196 & 191 & .029 \\
\hline 6 & Instagram & 3.015 & 1.080 & 60.3 & 0.200 & 191 & .841 \\
\hline 7 & Telegram & 2.833 & 0.999 & 56.6 & -2.311 & 191 & .022 \\
\hline 8 & TikTok & 2.260 & 0.957 & 45.2 & $\begin{array}{l}- \\
10.707\end{array}$ & 191 & .000 \\
\hline 9 & LinkedIn & 2.161 & 0.897 & 43.2 & $-\overline{1}-940$ & 191 & .000 \\
\hline \multirow[t]{2}{*}{10} & Snapchat & 1.593 & 0.987 & 31.8 & - & 191 & .000 \\
\hline & $\begin{array}{l}\text { Overall Types of social media } \\
\text { platforms }(N=192)\end{array}$ & 3.052 & 0.376 & 61.0 & 1.937 & 191 & .054 \\
\hline
\end{tabular}

* On a 5 -point Likert scale where $1=$ never, $2=$ rarely, $3=$ sometimes, $4=$ often, and $5=$ always.

$* *$ Test value is 3

\section{Level of Social Media Usage}

One sample t-test for the level of social media usage is presented in Table 5. The results show that, overall, seven in ten $(77.1 \%)$ of the respondents regard social media highly with mean of $3.858(\mathrm{SD}=0.715)$ and $(\mathrm{t}=16.619 ; \mathrm{p}=.000)$. They regard social media highly for several 
Volume 3 Issue 9 (June 2021) PP. 17-43 DOI: $10.35631 /$ IJPPSW.39003

reasons including; expressing their political views freely $(86.0 \%)$. This item also registered the highest mean of $4.302(\mathrm{SD}=0.807)$. the item that registered the lowest mean is item s3.7 "I use social media because it enables me to know my political opponents better" with $(\mathrm{M}=3.458$; $\mathrm{SD}=1.110$ ). this means that $69.1 \%$ of the respondents hardly use social media to know their political opponents better, but rather have other reasons which include; it is easy to communicate with their political parties $(85.4 \%)$ looking for information related to their political party's political activities $(81.3 \%)$, strengthens the relationship between them and their friends (79.5\%) and keeps them informed about the different political opinions (78.7\%). Others also include increasing their social media interaction with party leaders regarding party politics (75.3\%), willingness to continue using it in their daily social and political communication (72.7\%), enhancing their communication skills with friends from other political parties $(71.9 \%)$ and searching for accurate and trustworthy political information $(71.3 \%)$. The results confirm that the levels of social media usage among the respondents are high because all the items are significantly positive, and have some reasons why they regard them highly as discussed above.

Table 5: One-sample $t$-test for Social Media Usage

\begin{tabular}{|c|c|c|c|c|c|c|c|}
\hline No. & Social Media Usage & $\mathbf{M}^{*}$ & SD & $\%$ & $t^{* * *}$ & $d f$ & $\rho$ \\
\hline 1 & $\begin{array}{l}\text { I use social media to express my political } \\
\text { views freely. }\end{array}$ & 4.302 & 0.807 & 86.0 & 22.349 & 191 & .000 \\
\hline 2 & $\begin{array}{l}\text { I use social media because it is easy to } \\
\text { communicate with my political party. }\end{array}$ & 4.270 & 0.868 & 85.4 & 20.286 & 191 & .000 \\
\hline 3 & $\begin{array}{l}\text { I use social media to look for useful } \\
\text { information regarding my party's } \\
\text { political activities. }\end{array}$ & 4.067 & 0.886 & 81.3 & 16.688 & 191 & .000 \\
\hline 4 & $\begin{array}{l}\text { I use social media to strengthen the bond } \\
\text { between me and my friends. }\end{array}$ & 3.979 & 0.909 & 79.5 & 14.921 & 191 & .000 \\
\hline 5 & $\begin{array}{l}\text { I use social media to keep informed } \\
\text { about the different political opinions. }\end{array}$ & 3.937 & 0.968 & 78.7 & 13.409 & 191 & .000 \\
\hline 6 & $\begin{array}{l}\text { I use social media to increase my social } \\
\text { interaction with my party leaders } \\
\text { regarding party politics. }\end{array}$ & 3.765 & 1.084 & 75.3 & 9.786 & 191 & .000 \\
\hline 7 & $\begin{array}{l}\text { I am willing to continue using social } \\
\text { media as part of my daily communication } \\
\text { with my friends regarding social and } \\
\text { political interactions. }\end{array}$ & 3.635 & 1.117 & 72.7 & 7.880 & 191 & .000 \\
\hline 8 & $\begin{array}{l}\text { I use social media to enhance my } \\
\text { communication skills with my friends } \\
\text { from other political parties. }\end{array}$ & 3.599 & 1.018 & 71.9 & 8.149 & 191 & .000 \\
\hline 9 & $\begin{array}{l}\text { I } \log \text { in to social media to search for } \\
\text { accurate and trustworthy political-related } \\
\text { information about my party. }\end{array}$ & 3.567 & 1.005 & 71.3 & 7.823 & 191 & .000 \\
\hline 10 & $\begin{array}{l}\text { I use social media because it enables me } \\
\text { to know my political opponents better. }\end{array}$ & 3.458 & 1.110 & 69.1 & 5.717 & 191 & .000 \\
\hline & Overall Social Media Usage $(N=192)$ & 3.858 & 0.715 & 77.1 & 16.619 & 191 & .000 \\
\hline
\end{tabular}

$*$ On a 5 -point Likert scale where $1=$ never, $2=$ rarely, $3=$ sometimes, $4=$ often, and $5=$ always .

**Test value is 3 


\section{Level of Political Campaign Communication}

The level of political campaign communication is presented in Table 6. The respondent's views on political campaign communication are significantly positive $(72.3 \%)$ with an overall mean of $3.615(\mathrm{SD}=0.781)$ and $\mathrm{t}=10.904(\mathrm{p}=.000)$. the item with the highest mean is 1 "social media enables the quick organization of several political campaigns among users" with (4.010; $\mathrm{SD}=1.007$ ) which means that the majority of the respondents $80.2 \%$ believe that social media enables them to rally their supporters through an online campaign in a quick manner. However, the same respondents also had low responses for item 10 "I agree that social media provides solutions to many of my political problems" $(\mathrm{M}=3.099 ; \mathrm{SD}=1.234)$ which indicates that $61.9 \%$ of the respondents hardly believe that campaigning on social media can solve their political problems. Furthermore, other reasons why they regard campaign communication on social media highly include; enables them to convey their versions of politics and events (78.6\%), increases the visibility of political parties $(75.7 \%)$, reaching out to diverse voters (74.7\%), get involved more in politics $(73.9 \%)$, follow political commentary $(71.8 \%)$, express political views freely (69.7\%), mobilize supporters for the party $(68.4 \%)$ and also enables direct communication with party officials $(67.6 \%)$. The results mean that since almost all the items are significantly positive, the levels of political campaign communication are also high.

Table 6: One-sample $t$-test for Political Campaign Communication

\begin{tabular}{|c|c|c|c|c|c|c|c|}
\hline No. & Campaign Political Communication & $\mathbf{M}^{*}$ & SD & $\%$ & $t * *$ & $d f$ & $\rho$ \\
\hline 1 & $\begin{array}{l}\text { Social media enables the quick } \\
\text { organization of several political } \\
\text { campaigns among users. }\end{array}$ & 4.010 & 1.007 & 80.2 & 13.893 & 191 & .000 \\
\hline 2 & $\begin{array}{l}\text { I agree Social media enables me to } \\
\text { convey my version of politics and events. }\end{array}$ & 3.932 & 0.971 & 78.6 & 13.303 & 191 & .000 \\
\hline 3 & $\begin{array}{l}\text { I love using social media to increase the } \\
\text { visibility of my party. }\end{array}$ & 3.786 & 1.064 & 75.7 & 10.242 & 191 & .000 \\
\hline 4 & $\begin{array}{l}\text { Social media enables me to reach out to a } \\
\text { diversity of voters. }\end{array}$ & 3.739 & 1.030 & 74.7 & 9.941 & 191 & .000 \\
\hline 5 & $\begin{array}{l}\text { Social media enables me to get involved } \\
\text { more in politics }\end{array}$ & 3.697 & 1.088 & 73.9 & 8.881 & 191 & .000 \\
\hline 6 & $\begin{array}{l}\text { I get anxious when I don't have the } \\
\text { Internet available to access my social } \\
\text { media to follow political commentary. }\end{array}$ & 3.593 & 1.093 & 71.8 & 7.525 & 191 & .000 \\
\hline 7 & $\begin{array}{l}\text { I prefer to use social media in my free } \\
\text { time to express my political views freely. }\end{array}$ & 3.489 & 1.092 & 69.7 & 6.209 & 191 & .000 \\
\hline 8 & $\begin{array}{l}\text { I get more courage in mobilizing } \\
\text { supporters for my party using social } \\
\text { media. }\end{array}$ & 3.421 & 1.132 & 68.4 & 5.163 & 191 & .000 \\
\hline 9 & $\begin{array}{l}\text { Using social media enables me to get } \\
\text { direct communication with the different } \\
\text { political leaders. }\end{array}$ & 3.380 & 1.100 & 67.6 & 4.788 & 191 & .000 \\
\hline 10 & $\begin{array}{l}\text { I agree that campaigning social media } \\
\text { provides solutions to many of my } \\
\text { political problems. }\end{array}$ & 3.099 & 1.234 & 61.9 & 1.111 & 191 & .268 \\
\hline & $\begin{array}{ll}\text { Overall Political } & \text { Campaign } \\
\text { Communication }(N=192) & \end{array}$ & 3.615 & 0.781 & 72.3 & 10.904 & 191 & .000 \\
\hline
\end{tabular}

\footnotetext{
* On a 5-point Likert scale where $1=$ strongly disagree, $2=$ disagree, $3=$ slightly agree, $4=$ agree, and $5=$ strongly agree.
} 


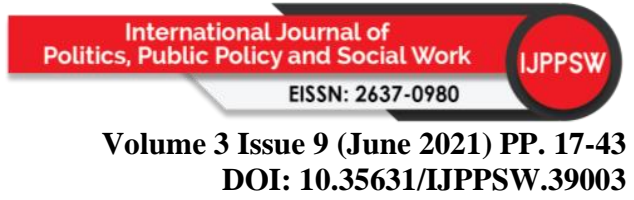

**Test value is 3 .

\section{Level of Political Polarization}

The levels of political polarization are presented in Table 7. Overall, the one-sample t-test results indicate that seven in ten $(71.3 \%)$ of the respondents believe that there is a high level of political polarization among the youths in Kampala and Wakiso districts with means of 3.568 $(\mathrm{SD}=0.635)$ and $\mathrm{t}=12.402(\mathrm{p}=.000)$. in addition, the item with the highest mean is "I sometimes use improper words while commenting on other people's political statements on social media" $(\mathrm{M}=4.052 ; \mathrm{SD}=0.854)$. this indicates that the majority $(81.0 \%)$ agree that they sometimes use inappropriate words while commenting on people's political commentaries. However, the item with the lowest means is "I am comfortable with my friends who have different political views from mine" $(\mathrm{M}=3.036$; $\mathrm{SD}=1.287)$. This item also turned out insignificant with $60.7 \%$ saying that they are hardly comfortable with their fellow friends who have views that are not in line with their political ambitions $t=0.392(p=.695)$. overall, since most of the items are significantly positive, the results mean that the levels of political polarization among youths are very high. Some of the reasons they consider them to be high include, social media does not protect users, constant social media fights regarding politics, disagreeing with the different political opinions, not valuing other people's political views, comment negatively on other people's pages, provoking others on social media regarding politics and many others.

Table 7: One-sample $t$-test for Political Polarization

\begin{tabular}{|c|c|c|c|c|c|c|c|}
\hline No. & Political Polarization & $\mathbf{M}^{*}$ & SD & $\%$ & $t * *$ & $d f$ & $\rho$ \\
\hline 1 & $\begin{array}{l}\text { I sometimes use improper words while } \\
\text { commenting on other people's political } \\
\text { statements on social media. }\end{array}$ & 4.052 & 0.854 & 81.0 & 17.059 & 191 & .000 \\
\hline 2 & $\begin{array}{l}\text { Social media rules do not protect users } \\
\text { and therefore they do more harm than } \\
\text { good among users. }\end{array}$ & 3.866 & 0.928 & 77.3 & 12.926 & 191 & .000 \\
\hline 3 & $\begin{array}{l}\text { I like commenting on other people's } \\
\text { political statements on social media. }\end{array}$ & 3.833 & 1.040 & 76.6 & 11.101 & 191 & .000 \\
\hline 4 & $\begin{array}{l}\text { I get stressed whenever I encounter } \\
\text { social media fights between political } \\
\text { opponents. }\end{array}$ & 3.802 & 0.998 & 76.0 & 11.129 & 191 & .000 \\
\hline 5 & $\begin{array}{l}\text { Social media allows freedom of speech } \\
\text { that enables hate speech among different } \\
\text { political actors. }\end{array}$ & 3.682 & 1.006 & 73.6 & 9.390 & 191 & .000 \\
\hline 6 & $\begin{array}{l}\text { I often disagree with my family members } \\
\text { because of our different political views. }\end{array}$ & 3.682 & 1.037 & 73.6 & 9.112 & 191 & .000 \\
\hline 7 & $\begin{array}{l}\text { I enjoy having political conversations } \\
\text { with my friends on social media. }\end{array}$ & 3.661 & 1.075 & 73.2 & 8.521 & 191 & .000 \\
\hline 8 & $\begin{array}{l}\text { Social media produces a lot of miss } \\
\text { information that leads to divisions among } \\
\text { different users. }\end{array}$ & 3.625 & 1.005 & 72.5 & 8.615 & 191 & .000 \\
\hline 9 & $\begin{array}{l}\text { I have a positive attitude towards other } \\
\text { political party views on social media. }\end{array}$ & 3.593 & 1.078 & 71.8 & 7.626 & 191 & .000 \\
\hline 10 & I do not value other people's views & 3.536 & 1.161 & 70.7 & 6.399 & 191 & .000 \\
\hline
\end{tabular}


Volume 3 Issue 9 (June 2021) PP. 17-43 DOI: $10.35631 /$ IJPPSW.39003

11 I often comment negatively on the socia media pages of my political opponents.

12 Social media bullying encourages divisive political communication among users.

13 I always provoke others in my political views shared on social media.

14 I always receive divisive political messages on social media.

15 I always stay away from divisive political discussions on social media.

$\begin{array}{llllll}3.505 & 1.171 & 70.1 & 5.977 & 191 & .000\end{array}$

$\begin{array}{llllll}3.500 & 1.120 & 70.0 & 6.181 & 191 & .000\end{array}$

$\begin{array}{llllll}3.343 & 1.142 & 66.8 & 4.169 & 191 & .000\end{array}$

$\begin{array}{llllll}3.296 & 1.202 & 65.9 & 3.422 & 191 & .001\end{array}$

16 I tolerate different political views while on social media.

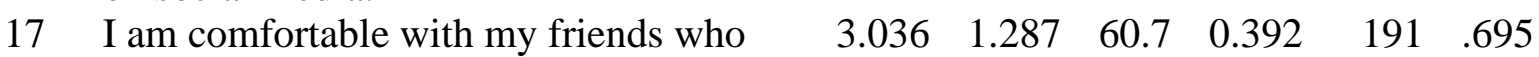
have different political views from mine.

$\begin{array}{lllllll}\text { Overall political polarization }(N=192) & 3.568 & 0.635 & 71.3 & 12.402 & 191 & .000\end{array}$

* On a 5-point Likert scale where $1=$ never, $2=$ rarely, $3=$ sometimes, $4=$ often, and $5=$ always.

**Test value is 3 .

\section{Zero-Order Correlation Between the Given Variables}

Research objective 5 is concerning determining the relationship between social media platforms, social media usage, and political communication which are the independent variable, and political polarization as the dependent variables amongst youths in Uganda. Zeroorder correlation is performed to measure the relationship between the given variables. The results reveal that there exist both weak strong significant relationships between the variables hence accepting $\mathrm{H} 4$ which states that there is a relationship between types of social media platforms, social media usage, campaign political communication with political polarization. The results from the test are presented in Table 8 and are further broken down in specific details regarding each relationship.

Table 8: Zero-order Correlation Between the Given Variables

\begin{tabular}{|c|c|c|c|c|}
\hline Variable $(N=192)$ & $\begin{array}{l}\text { Political } \\
\text { Polarization }\end{array}$ & $\begin{array}{l}\text { Types of } \\
\text { Social Media } \\
\text { platforms }\end{array}$ & $\begin{array}{l}\text { Social } \\
\text { Media } \\
\text { Usage }\end{array}$ & $\begin{array}{l}\text { Political Campaign } \\
\text { Communication }\end{array}$ \\
\hline $\begin{array}{l}\text { Political } \\
\text { Polarization }\end{array}$ & 1 & & & \\
\hline $\begin{array}{l}\text { Types of Social } \\
\text { Media platforms }\end{array}$ & $\begin{array}{l}r=.201 * *, \\
\rho=.003\end{array}$ & 1 & & \\
\hline $\begin{array}{l}\text { Social Media } \\
\text { Usage }\end{array}$ & $\begin{array}{l}r=.641^{* *}, \\
\rho=.000\end{array}$ & $\begin{array}{l}r=.094 * *, \\
\rho=.097\end{array}$ & 1 & \\
\hline $\begin{array}{l}\text { Pol-Campaign } \\
\text { Communication }\end{array}$ & $\begin{array}{l}r=.664^{* *}, \\
\rho=.000\end{array}$ & $\begin{array}{l}r=.098^{* *}, \\
\rho=.088\end{array}$ & $\begin{array}{l}r \\
.696 * * \\
\rho=.000\end{array}$ & 1 \\
\hline
\end{tabular}

The results from the bivariate correlation indicate that there is a weak insignificant relationship between the types of social media platforms and political polarization $(r=.201, \rho=.003)$. this result indicates that $\mathrm{H} 1$ which states that there is a positive relationship between types of social media platforms and political polarization is not supported. This translates that, much as the 


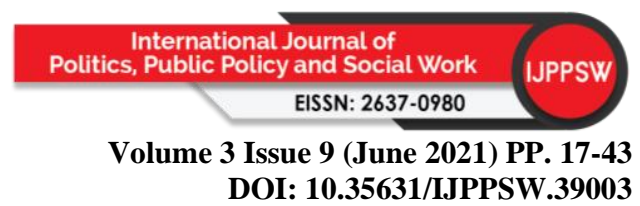

respondents use the different social media platforms to engage in social and political activities while online, they hardly use all the platforms and that they are selective in the ones that they often use in politics.

Furthermore, there is a strong statistically significant relationship between social media usage and political polarization $(r=.641, \rho=.000)$, a finding that supports $\mathrm{H} 2$ which states that there is a positive relationship between social media usage and political polarization. The finding translates that, the more the youths use social media while engaging in political discussions, the more they will be polarized towards their political inclinations. This finding is also supported by Zhang et al. (2010) who in their study found out that, relying on social network sites such as Facebook and Twitter was positively related to civic participation but also in the likelihood of separating users with dissent political views.

Similarly, there is a strong statistically significant relationship between campaign political communication and political polarization as a result of using social media $(r=.664, \rho=.000)$; hence, $\mathrm{H} 3$ is supported in the positive. This means that the more the youths and the apolitical actors use social media for political campaign communication, the more they will be promoting divisionism among the youths because social media is so addictive and can easily sway one's support by simply feeding them with information that they are looking forward to hearing even if it is not correct. Therefore, but spreading wrong and the right information, one can easily pick a side where they want to belong and might never want to hear anything related to the opposite side and hence polarization takes effect.

\section{Discussion}

The study examines the role of social media in political campaign communication and its impact on political polarization among youths in Kampala and Wakiso, Uganda. A considerable number of respondents revealed that they are selective in the types of platforms that they consider using while engaging in political discussions while online. This helps them not to be redundant and rather be responsible as opening many platforms may result in redundancy of the content in some particular platforms and also attracts miss information in one way or the other. This finding corresponds with that of Williams and Gulati (2007, 2009) who concluded that platforms such as Facebook and Twitter are more influential when used to transmit a message that is desired to reach multitudes of recipients because the message has a likelihood of going viral because of being selective with the type of platform that one chooses to use while sending such a message.

In the end, the platforms once are selected carefully, play an important role in communicating the intended messages to their recipients. This study also finds out that Facebook, WhatsApp, Twitter, Instagram, and messenger as some of the platforms that are often used by Ugandan youths while engaging in online and social-political discussions. However, platforms such as TikTok, LinkedIn, telegram, and others were found to hardly be useful in political communication especially while dealing with ass audiences. This could be partly because the ones that are often used are very quick to be replicated and are widely subscribed by almost all the youths in the country. Furthermore, they are also very dominant, unlike the latter which are only preferred for different reasons other than online political discussions as well as participation.

Furthermore, the majority of the youths in Uganda use social media to strengthen their interpersonal relationships with their peers as well as engaging them in political discussions 


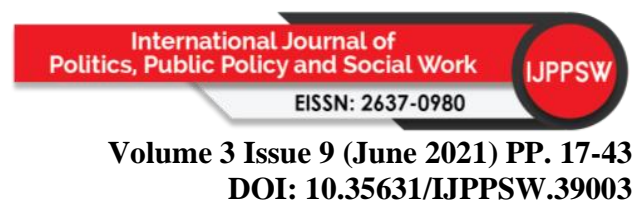

freely, thereby rendering high levels of political polarization. The results are supported by findings of Roosblad (2016) who found out that, Facebook offers young people a platform and an opportunity to express their views freely, and also for politicians and political parties to reach individuals that were less interested in politics. Also, Kushin and Kitchener (2009) also explored the use of Facebook for online political discussions, where the results of their study did not differ with the findings of the current study in agreeing that indeed Facebook and other selected and preferred social network platforms are reasonable platforms to discuss political issues while engaging online. This study also singled out reasons such as discussing politics freely, communicating with political parties, getting information regarding the politics of the different political parties, and more as the reasons why the respondents regard social media usage in politics highly.

Similarly, this research also found out that smartphones almost all the respondents use smartphones to access their social media platforms. Facebook was singles out as the most popular platforms that the majority of the respondents use and sometimes refer to while looking for political-related information online. This finding is also in tandem with the findings of Wok and Mohamed (2017) who note that while social media users are surfing the internet, they mainly use Facebook and WhatsApp to connect with friends whether socially and or politically. However, this present study also revealed that much as social media enables users to express their political views freely and as well engage in political discussions while online, the same study also notes that social media cannot be a solution to all the user's political problems and ambitions, as well as aspirations. This might be because some political issues are better off resolved face to face with the electorates as well as the politicians and political activists rather than just engaging in political discussions online that might not produce immediate feedback and solution to the user's immediate problem and or issue. therefore, it is wise to always use social media for one's political gains but also put into consideration that they hardly solve every single political problem.

Also, the results reveal that campaign political communication on social media enables the quick organization of online political campaigns among users. This study also notes that young people also tend to convey their political minds through freely expressing themselves on social media which also necessitates their parent political parties to notice and recognize their contributions to the party politics while encouraging more supporters using social media.

The above findings conform with many scholars who contend that the vast majority of politicians use social media as a campaigning medium for maintaining their public image, and as a communication medium for sustaining engagement with journalists and their potential audience (Howard et al., 2017), something that the present study has brought out more clearly after finding out that respondents prefer to use social media to keep tabs of their political parties and their respective political activities, although all the platforms do not necessarily translate into possible solutions to the respondent's political problems as it was hinted on in the above findings.

Similarly, the study also illustrates that the more the users engage fellow users on social media, the more they become more involved in politics and always get anxious whenever they lack internet connectivity to follow political commentary that they ate often used to while engaging each other online. This however culminates into a situation where the more they get involved in online campaign political communication, the more they are likely to get divided based on 


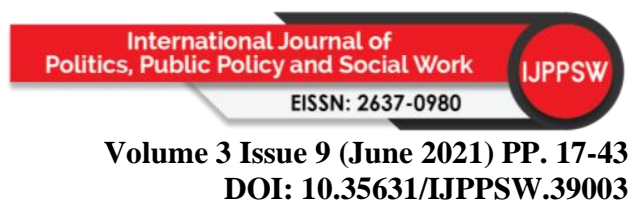

the political sentiments that they keep discussing amongst them, and hence polarization takes effect.

The study however also reveals that the youths in Uganda hardly consider social media as the direct link between them and their political leader however much it may act as one of the quickest means to do so, but they contend that, there are several other ways of reaching their political party leaders in case they need any political-related information and or advice from them concerning any political matter. Also, the platforms are not the sole political problem solvers.

Lastly, the current study found out that social media users sometimes use improper words while commenting on other user's political pages and statements that they publish on their social media platforms. They also contend that the social media rules do not protect users which makes the situation worse and therefore does more harm than good because, in the end, the platforms may lead to divisionism amongst the users.

The findings also reveal that there is total agreement between the current study and that of Levendusky (2013) who in his study found out that, by presenting politics as a struggle between opposed parties that cannot reconcile, social media makes audiences' partisan identities more prominent, thus contributing to both perceptive and affective divisions.

Furthermore, the study of Garrett et al. (2016) also adds in agreement to the current one that, exposure to ideologically biased social platforms is positively associated with holding inaccurate beliefs on politically relevant issues even if people are aware of the facts contradicting such beliefs. These issues are manifested in the present study where results hint at the constant comments of the users on their friend's political statements and pages on social media but with negative comments.

The findings from the present study also indicate that the users tend to satisfy their needs of engaging with their family members where most political disagreements may be realized and that several of them hold negative political views emanating from their party social media platforms. The youths also are in agreement that social media political bullying encourages political division amongst the young people who hardly have enough experience regarding political matters.

The respondents also reiterated that they cannot just stay away from the online divisive political discussions simply because they have to always provide the necessary and required information regarding the topical discussion at the time. However, they hardly tolerate different political opinions on social media and are not necessarily comfortable with friends who hold different political views from different political backgrounds.

All in all, this study has proved that the uses and gratification theory guided the study well and that the several platforms chosen by users in most cases lead to using of the social media in different ways including applying it in campaigning online that in most cases results into divisive politics among the users and the public. Once the users are polarized, it is not an easy task to depolarize them because online information is very fast and is always aimed at going viral whenever it circulates. 


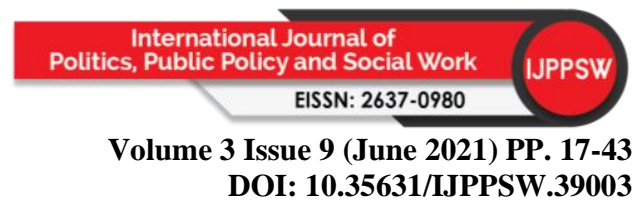

\section{Conclusion}

DOI: 10.35631/IJPPSW.39003

In conclusion, the respondents of the study consisted of 192 Kampala and Wakiso male urban residents in their young ages with some of them at least having an ordinary/advanced level of education as well as a degree. Also, the majority of the respondents use smartphones to access social media where they spend more than an hour using it daily and weekly while looking for political information. Also, most of them regard it as slightly important in politics.

The general relationships between the variables show that the types of social media platforms, social media usage, and campaign political communication correlates with political polarization which translates that, the more the users pick a platform, uses social media to engage in online campaign political communication, the more they are likely to be polarized because as human beings, we do not think the same and that the message they might be circulating might not be ideal for me thereby causing a polarized environment where I would be most likely comfortable seeing information that I most relate with. The findings of the study also support the usage of the uses and gratifications theory (UGT) as the theory used to guide the present study.

\section{Limitations of the Study}

There were some limitations while conducting the present study and some of them are as follows;

The study was limited to only the districts of Kampala and Wakiso. This observation is important because it leaves a gap in the representation of the other remaining districts. After all, they also participate in the politics of the country and are also possibly receiving the same online content on social media. thus the findings may not fully represent the entire country's (Uganda) population therefore, the results may be interpreted with caution.

Data collection was done during a politically tense period where many people were engaging in political activities but also, COVID-19 affected the process because most people did not want to be physically approached and that they preferred online engagements. This is the process and hence because slow and poor response rates were registered.

The study only used one method to collect data from the respondents. Such studies are usually broad and may require using a mixed-method approach to bring out a nuanced picture.

The study also used the uses and gratifications theory. Many other theories could have opted for the current study.

\section{Suggestions for Future Research}

Theoretically, further studies could be conducted using other theories such as the media agenda theory, framing theory, media dependency theory, and many others as may suit the phenomenon under study at the time. This could help in exploring more hidden data and relationships that the uses and gratifications theory might not have brought out clearly in the present study.

Population-wise, the study had only considered residents of Kampala and Wakiso districts. This population might not necessarily represent the entire population of Uganda. Therefore, future researchers are advised to opt for more districts that use the internet and social media in particular and see whether the findings could change as a result of the addition of such information. Also. Generalization of results to the whole country basing on these two districts 


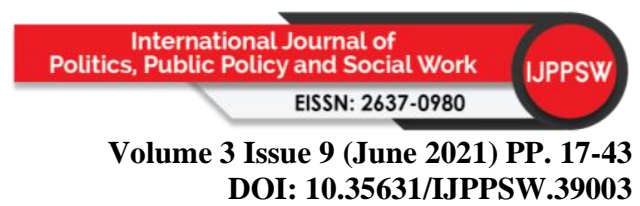

might prove to be difficult as the country has a very big population of more than 45 million people.

On data analysis, the current study only uses SPSS, however, future studies could explore polarization among the users through the use of AMOS Software through structural equation modeling (SEM) because it is known for extracting well the covariance and variances between constructs and enables proper carrying out of the relationships that exist between the variables. On the method of data collection, further studies could explore more details by adding on another method possibly an interview to talk to political experts and understand the issue from an in-depth point of view rather than only relying on the perception of the young people who might not even know the effects of polarization among themselves.

\section{References}

Al-Jabri, I.M., Sohail, M.S. and Ndubisi, N.O. (2015), Understanding the usage of global social networking sites by Arabs through the lens of uses and gratifications theory. Journal of Service Management.

Ansolabehere, S., Snyder Jr, J. M., \& Stewart III, C. (2000). Old voters, new voters, and the personal vote: Using redistricting to measure the incumbency advantage. American Journal of Political Science, 17-34.

Berinsky, Adam J. (2017). "Rumors and Health Care Reform: Experiments in Political Misinformation.” British Journal of Political Science. 47(2): 241-262.

Blumler, J. G., \& Katz, E. (1974). The Uses of Mass Communications: Current Perspectives on Gratifications Research. Sage Annual Reviews of Communication Research Volume III.

Boyd, D. M., \& Ellison, N. B. (2007). Social network sites: Definition, history, and scholarship. Journal of computer-mediated communication, 13(1), 210-230.

Chen, G. M. (2011). Tweet this: A uses and gratifications perspective on how active Twitter use gratifies a need to connect with others. Computers in human behavior, 27(2), $755-762$.

Cheung, C. M., \& Lee, M. K. (2010). A theoretical model of intentional social action in online social networks. Decision support systems, 49(1), 24-30.

Cheung, C. M., Chiu, P. Y., \& Lee, M. K. (2011). Online social networks: Why do students use facebook? Computers in human behavior, 27(4), 1337-1343.

Communication Studies. "Uses and Gratifications theory. Retrieved: November 15, 2020. http://www.communicationstudies.com/communication-theories/uses-and gratifications-theory.

Conover, M. D., Ratkiewicz, J., Francisco, M. R., Gonçalves, B., Menczer, F., \& Flammini, A. (2011). Political polarization on twitter. Icwsm, 133(26), 89-96.

Creswell, J. W. (2014). A concise introduction to mixed methods research. SAGE publications.

Creswell, J. W., \& Creswell, J. D. (2017). Research design: Qualitative, quantitative, and mixed methods approaches. Sage publications.

Dhir, A., \& Tsai, C. C. (2017). Understanding the relationship between intensity and gratifications of Facebook use among adolescents and young adults. Telematics and Informatics, 34(4), 350-364.

Eurostat. (2017). Digital economy \& society in the EU [report]

Eurostat. (2018). Digital economy \& society in the EU [report]

Facebook Newsroom. (2019). 'Company Info' [webpage]

Franklin, C., \& Ballan, M. (2001). Reliability and validity in qualitative research. The handbook of social work research methods, 4, 273-292.

Copyright $\odot$ GLOBAL ACADEMIC EXCELLENCE (M) SDN BHD - All rights reserved 


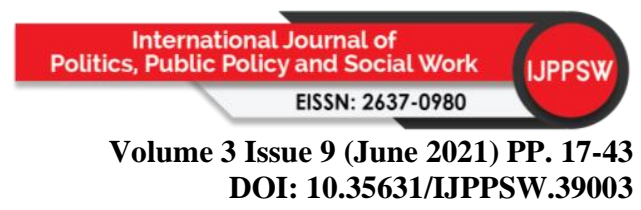

Gans, J. S., Goldfarb, A., and Lederman, M. (2016). Exit, tweets, and loyalty. University of Toronto working paper.

Gan, C. (2017). Understanding WeChat users' liking behavior: An empirical study in China. Computers in human behavior, 68, 30-39.

Garrett, R. K., Gvirsman, S. D., Johnson, B. K., Tsfati, Y., Neo, R., \& Dal, A. (2014). "Implications of Pro-and Counterattitudinal Information Exposure for Affective Polarization." Human Communication Research 40(3), 309-332.

Gil de Zúñiga, H., Veenstra, A., Vraga, E., \& Shah, D. (2010). Digital democracy: Reimagining pathways to political participation. Journal of information technology \& politics, 7(1), $36-51$.

Gillespie, T. (2014a). Media Technologies: Essays on Communication, Materiality, and Society. In T. Gillespie, P. Boczkowski, \& K. Foot (Eds.), Media Technologies: Essays on Communication, Materiality, and Society. The MIT Press.

Gong, S., Zhang, J., Zhao, P., and Jiang, X. (2017). Tweeting as a marketing tool: A field experiment in the tv industry. Journal of Marketing Research, 54(6):833-850.

Groves, R. M. (2011). Three eras of survey research. Public opinion quarterly, 75(5), 861-871.

Harridge-March, S., Dunne, Á., Lawlor, M. A., \& Rowley, J. (2010). Young people's use of online social networking sites-a uses and gratifications perspective. Journal of Research in interactive Marketing.

Howard, P. N., \& Parks, M. R. (2012). Social Media and Political Change: Capacity, Constraint, and Consequence. Journal of Communication, 62(2), 359-362.

Howard, P. N., Savage, S., Saviaga, C. F., Toxtli, C., \& Monroy-Hernández, A. (2016). Social media, civic engagement, and the slacktivism hypothesis: Lessons from Mexico's "El Bronco". Journal of International Affairs, 70(1), 55-73.

Howard, P. N., \& Kollanyi, B. (2016). Bots, \# StrongerIn, and\# Brexit: computational propaganda during the UK-EU referendum. Available at SSRN 2798311.

Hsiao, C. H., Chang, J. J., \& Tang, K. Y. (2016). Exploring the influential factors in continuance usage of mobile social Apps: Satisfaction, habit, and customer value perspectives. Telematics and Informatics, 33(2), 342-355.

Iyengar, Shanto, Gaurav Sood, and Yphtach Lelkes. (2012). "Affect, Not Ideology: A Social Identity Perspective on Polarization.” Public Opinion Quarterly 76(3): 405-431.

Kosloff, Spee, Jeff Greenbern, Tom Schmader, Tom Dechesne, and David Weise. (2010). "Smearing the Opposition: Implicit and Explicit Stigmatization of the 2008 U.S. Presidential Candidates and the Current U.S. President." Journal of Experimental Psychology: General 139(3): 383-398.

Kumar, V., Bhaskaran, V., Mirchandani, R., \& Shah, M. (2013). Practice prize winner creating a measurable social media marketing strategy: increasing the value and ROI of intangibles and tangibles for hokey pokey. Marketing Science, 32(2), 194-212.

Laroche, M., Habibi, M. R., \& Richard, M. O. (2013). To be or not to be in social media: How brand loyalty is affected by social media? International journal of information management, 33(1), 76-82.

Levendusky, M. S. (2013). "Why do Partisan Media Polarize Viewers?" American Journal of Political Science 57(3), 611-623.

Li, H., Liu, Y., Xu, X., Heikkilä, J., \& Van Der Heijden, H. (2015). Modeling hedonic is continuance through the uses and gratifications theory: An empirical study in online games. Computers in Human Behavior, 48, 261-272.

Margetts, H., John, P., Hale, S., \& Yasseri, T. (2015). Political turbulence: How social media shape collective action. Princeton University Press. 


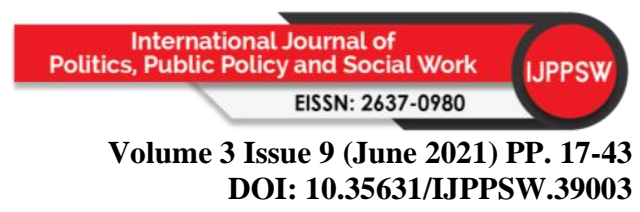

Nielsen, R. K. (2014). The many crises of Western journalism: A comparative analysis of economic, professional, and simbolic crises. In The Crisis of Journalism Reconsidered: Cultural Power.

Neudert, L. M., \& Marchal, N. (2019). Polarization and the use of technology in political campaigns and communication. Study Panel for the Future of Science and Technology, European Parliamentary Research Service, Brussels.

Nulty, P., Theocharis, Y., Popa, S. A., Parnet, O., \& Benoit, K. (2016). Social media and political communication in the 2014 elections to the European Parliament. Electoral studies, 44, 429-444.

Onwuegbuzie, A. J., \& Johnson, R. B. (2006). The validity issue in mixed research. Research in the Schools, 13(1), 48-63.

Park, N., Kee, K. F., \& Valenzuela, S. (2009). Being immersed in social networking environment: Facebook groups, uses and gratifications, and social outcomes. Cyber psychology \& behavior, 12(6), 729-733.

Prat, A. (2002). Campaign advertising and voter welfare. The Review of Economic Studies, 69(4), 999-1017.

Prior, M. (2006). The incumbent in the living room: The rise of television and the incumbency advantage in US House elections. The journal of Politics, 68(3), 657-673.

Roosblad S (2016). Social Media Offers Young Voices a Platform During Uganda Election. Retrieved on November 14the 2020, from https://www.voanews.com/africa/socialmedia- offers-young-voices-platform-during-uganda-election.

Ruggiero, T. E. (2000). Uses and gratifications theory in the 21 st century. Mass communication \& society, 3(1), 3-37.

Saunders, M., Lewis, P., \& Thornhill, A. (2007). Research methods for business. London: Pitman,124-126.

Song, I., Larose, R., Eastin, M. S., \& Lin, C. A. (2004). Internet gratifications and Internet addiction: On the uses and abuses of new media. Cyber psychology \& behavior, 7(4), 384-394.

Stroud, N. J. (2011). Niche news: The politics of news choice. Oxford University Press on Demand.

Tucker, J. A., Theocharis, Y., Roberts, M. E., \& Barberá, P. (2017). From liberation to turmoil: Social media and democracy. Journal of democracy, 28(4), 46-59.

Tumasjan, A., Sprenger, T. O., Sandner, P. G., \& Welpe, I. M. (2011). Election forecasts with Twitter: How 140 characters reflect the political landscape. Social science computer review, 29(4), 402-418.

Weeks, B. E., \& Garrett, R. K. (2014). Electoral consequences of political rumors: Motivated reasoning, candidate rumors, and vote choice during the 2008 US presidential election. International Journal of Public Opinion Research, 26(4), 401-422.

$\mathrm{Wu}, \mathrm{T}$. (2016). The attention merchants: the epic scramble to get inside our heads. Atlantic Books.

Zhang, W., Johnson, T. J., Seltzer, T., \& Bichard, S. L. (2010). The revolution will be networked: The influence of social networking sites on political attitudes and behavior. Social Science Computer Review, 28(1), 75-92. 